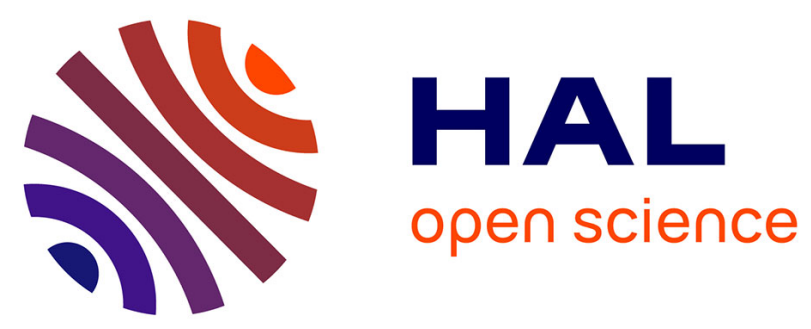

\title{
Regulation of growth, protein synthesis, and maturation of fetal bovine epiphyseal chondrocytes grown in high-density culture in the presence of ascorbic acid, retinoic acid, and dihydrocytochalasin $B$.
}

Anne-Marie Freyria, Marie-Claire Ronzière, S. Roche, Cécile F. Rousseau, Daniel Herbage

\section{To cite this version:}

Anne-Marie Freyria, Marie-Claire Ronzière, S. Roche, Cécile F. Rousseau, Daniel Herbage. Regulation of growth, protein synthesis, and maturation of fetal bovine epiphyseal chondrocytes grown in highdensity culture in the presence of ascorbic acid, retinoic acid, and dihydrocytochalasin B.. Journal of Cellular Biochemistry, 1999, 76 (1), pp.84-98. 10.1002/(SICI)1097-4644(20000101)76:13.0.CO;2-Z . hal-00313321

\section{HAL Id: hal-00313321 \\ https://hal.science/hal-00313321}

Submitted on 14 Dec 2017

HAL is a multi-disciplinary open access archive for the deposit and dissemination of scientific research documents, whether they are published or not. The documents may come from teaching and research institutions in France or abroad, or from public or private research centers.
L'archive ouverte pluridisciplinaire HAL, est destinée au dépôt et à la diffusion de documents scientifiques de niveau recherche, publiés ou non, émanant des établissements d'enseignement et de recherche français ou étrangers, des laboratoires publics ou privés. 


\title{
Regulation of G rowth, Protein Synthesis, and Maturation of Fetal Bovine Epiphyseal Chondrocytes G rown in High-Density Culture in the Presence of Ascorbic Acid, Retinoic Acid, and Dihydrocytochalasin B
}

\author{
Anne-Marie Freyria,* Marie-Claire Ronzière, Stéphane Roche, Cécile F. Rousseau, and D aniel Herbage \\ Institut de Biologie et Chimie des Protéines, CN RS-U PR, 69367 Lyon Cedex 07, France
}

\begin{abstract}
Phenotypic expression of chondrocytes can be modulated in vitro by changing the culture technique and by agents such vitamins and growth factors. We studied the effects of ascorbic acid, retinoic acid (0.5 and $10 \mu \mathrm{M})$, and dihydrocytochalasin $\mathrm{B}(3,10,20 \mu \mathrm{M} \mathrm{DHCB}$ ), separately or in combination (ascorbic acid + retinoic acid or ascorbic acid + DHCB), on the induction of maturation of fetal bovine epiphyseal chondrocytes grown for up to 4 weeks at high density in medium containing $10 \%$ fetal calf serum and the various agents. In the absence of any agent or with retinoic acid or D HCB alone, the metabolic activity of the cells remained very low after day 6 , with no induction of type I or X collagen synthesis nor increase in alkaline phosphatase activity. Chondrocytes treated with fresh ascorbic acid showed active protein synthesis associated with expression of types I and X after 6 and 13 days, respectively. This maturation was not accompanied by obvious hypertrophy of the cells or high alkaline phosphatase activity. Addition of retinoic acid to the ascorbic acid-treated cultures decreased the level of type II collagen synthesis and delayed the induction of types I and $X$ collagen, which were present only after 30 days. A striking increase in alkaline phosphatase activity (15-20-fold) was observed in the presence of both ascorbic acid and the highest dose of retinoic acid $(10 \mu \mathrm{M})$. D HCB was also a potent inhibitor of the maturation induced by treatment with ascorbic acid, as the chondrocytes maintained their rounded shape and synthesized type II collagen without induction of type I or X collagen. The pattern of protein secretion was compared under all culture conditions by two-dimensional gel electrophoresis. The different regulations of chondrocyte differentiation by ascorbic acid, retinoic acid, and DHCB were confirmed by the important qualitative and quantitative changes in the pattern of secreted proteins observed by tw o-dimensional gel electrophoresis along the study.
\end{abstract}

Key words: chondrocyte maturation; collagen types I, II, and X; ascorbic acid; retinoic acid; dihydrocytochalasin B

During endochondral ossification, chondrocytes undergo maturation from resting and proliferating cells to hypertrophic cells [Brighton, 1978; Hunzinker, 1994]. This maturation process is controlled by programmed events, with changes in cell morphology and qualitative and quantitative variations in the synthesis of matrix macromolecules. Culture conditions and the presence of agents such as vitamins and

Grant sponsor: BIOMED 2; Grant number: BMH4-CT950396; Grant sponsor: Rhône-Alpes Région; Grant number: L094120401.

*Correspondence to: Anne-Marie Freyria, IBCP, CNRSUPR 412, 7, Passage du Vercors, 69367 Lyon Cedex 07, France. E-mail: am.freyria@ibcp.fr

Received 22 March 1999; Accepted 15J une 1999 growth or differentiation factors can modulate the phenotypic expression of the chondrocytes [Solursh, 1989; Sandberg, 1991; Adolphe and Benya, 1992; Cancedda et al., 1995; Labourdette et al., 1996; Hickok et al., 1998]. After release from their cartilagenous matrix, rabbit differentiated articular chondrocytes grown in a monolayer on plastic surfaces rapidly lose their initial phenotype [Benya et al., 1978]. Under culture conditions that limit their attachment and proliferation, in liquid suspension [Horwitz and Dorfman, 1970; Pacifici and Oettinger, 1985; Tacchetti et al., 1987] or in a three-dimensional matrix such as agarose [Benya and Shaffer, 1982; Aydel otte et al., 1986], alginate beads [Guo et al., 1989; Häuselmann et al., 1992], or collagen gels [Gibson et al., 
1982; Kimura et al., 1984], chondrocytes from various sources maintain their rounded configuration and a cartilage phenotype. Inhibition of chondrocyte spread by a high initial cell seeding density on plastic or by using the cell pellet technique has been shown by several authors to allow simple culture conditions for analysis of changes in chondrocyte gene expression during maturation in vitro. Under these conditions, fetal bovine epiphyseal or adolescent bovine articular cells [Harmand et al., 1982; Kuettner et al., 1982; Daniel et al., 1984; Ruggiero et al., 1993; Hering et al., 1994; F reyria et al., 1995a,b; Ronziere et al., 1997], chicken growth plate cells [Farquharson and Whitehead, 1995] rabbit growth plate cells [Kato et al., 1988; I wamoto et al., 1989], or rat epiphyseal cells [Ballock et al., 1993] rapidly synthesize their own extracellular matrix, form multicellular layers, and can be maintained in culture for longer than 1 month.

Ascorbic acid and retinoic acid, factors known to modulate the phenotype of the chondrocytes, were frequently added in the different culture systems described to study the chondrocyte maturation. Most of these studies were conducted in chicken embryo utilizing either vertebra [Oettinger and Pacifici, 1990; Gerstenfeld and Landis, 1991; Adams et al., 1991] or sterna (caudal as immature chondrocyte zone and cephalic as mature chondrocyte region) [Yasui et al., 1986; Horton et al., 1987; Bruckner et al., 1989; Leboy et al., 1989; Dietz et al., 1993; I wamoto et al., 1993a,b, 1994; Sullivan et al., 1994; Chen et al., 1995; Leboy et al., 1997; Venezian et al., 1998]. The chicken growth plate was also frequently used [Castagnola et al., 1986; Takishita et al., 1990; Wu et al., 1997; Nie et al., 1998]. These studies and studies with chondrocytes from other species such as quail [Sanchez et al., 1991], rat [Ballock et al., 1993], rabbit [Kato et al., 1988; I wamoto et al., 1989], bovine [Hering et al., 1994; K oyano et al., 1996], and human [Kirsch et al., 1992; Stephens et al., 1992] and from different tissues showed that all of the cell types analyzed could undergo a sequence of changes up to the final maturation with type $X$ collagen synthesis and increase in alkaline phosphatase activity, depending on the culture conditions and on the presence of appropriate activating agents. Thus, cells from the reserve (resting) zoneand the permanent articular region can undergo hypertrophy, although at a slower rate than cells from the growth plate.

In previous studies, we determined the composition and organization of the collagen network produced by fetal bovine epi physeal chondrocytes in long-term culture at high density [Ruggiero et al., 1993] and the effect on these parameters of retinoic acid [Freyria et al., 1995a,b] and ascorbic acid [Ronziere et al., 1997]. In this paper, we report a study conducted to examine phenotypic modulation of the cells in the same culture model in the presence of ascorbic acid, retinoic acid (0.5 or 10 $\mu \mathrm{M})$ and dihydrocytochalasin B (DHCB, 3, 10, and $20 \mu \mathrm{M}$ ), added separately or in combination (ascorbic acid + retinoic acid or ascorbic acid + DHCB). Cell morphology and proliferation, synthesis of total protein and collagen types I, II, and $X$ in the cell layer and the medium and alkaline phosphatase activity were characterized under various culture conditions and various lengths of culture. The pattern of secreted proteins was determined by two-dimensional el ectrophoresis in order to eluci date the qualitative and quantitative modifications induced by thesefactors in fetal bovineepiphyseal chondrocytes.

\section{MATERIALS AND METHODS Cell Culture}

Chondrocytes were isolated by enzymatic digestion from the reservezone of the distal femoral epi physes of 4-month-old bovine fetuses (five different animals were used in this study) after careful removal of the articular surface and the growth plate. They are noted here "fetal bovine epiphyseal chondrocytes" according to Koyano et al. [1996]. Chondrocytes were cultured at high density $\left(0.8 \times 10^{6}\right.$ cells/ $\left./ \mathrm{cm}^{2}\right)$ in RPMI/ NCTC medium containing $10 \%$ fetal calf serum and antibiotic supplements, in the absence or presence of freshly prepared ascorbic acid (25 $\mu \mathrm{g} / \mathrm{ml}$ ) throughout the culture. The medium was changed every three days, as previously described [Ruggiero et al., 1993; F reyria et al., 1995a; Ronzière et al., 1997]. All-trans retinoic acid or DHCB was dissolved in 95\% ethanol and added to the culture media at a volume of $0.2 \%$ after 2 days of culture and when the treated cultures were fed. Cells cultured with retinoic acid received 0.5 or $10 \mu \mathrm{M}$ for $4,11,21$, or 28 days, whereas cells cultured with DHCB received 3,10 , or $20 \mu \mathrm{M}$ for 11 or 21 days; the control cultures received the same amounts of 
ethanol. The cultures were analyzed after 6,13 , 23 , and 30 days of culture.

\section{Electron Microscopy}

For transmission electron microscopy, cultures were fixed in $2 \%$ glutaraldehyde in phosphate-buffered saline for $30 \mathrm{~min}$ at room temperature and post-fixed in $2 \%$ osmium tetroxide in phosphate-buffered saline for $1 \mathrm{~h}$. After dehydration in successive dilutions of ethanol, the material was embedded in E pon. Thin sections were mounted on copper grids, stained with uranyl acetate, and lead citrate and observed on a J eol 1200 EX electron microscope at a voltage of $80 \mathrm{kV}$.

For scanning electron microscopy, cultures were fixed in a $4 \%$ glutaral dehyde cacodylatebuffered solution for $1 \mathrm{~h}$ at room temperature then washed for $1 \mathrm{~h}$ with $0.4 \mathrm{M}$ sodium cacodylate, $\mathrm{pH} 7.4$, and $360 \mathrm{mOsmol} / \mathrm{L}$. The samples were dehydrated by acetone diffusion, critical point-dried, coated with gold palladium, and viewed under a S800 Hitachi microscope at 15 $\mathrm{kV}$. All of these experiments were performed at the Centre for Electron Microscopy Applied to Biology and Geology, Université Claude Bernard, Lyon.

\section{Analytical Procedures}

Protein synthesis after 12 and 22 days of culture of DHCB-treated cells was measured by labelling duplicate cultures with $8 \mu \mathrm{Ci} / \mathrm{ml}$ of ${ }^{14} \mathrm{C}$-proline $(290 \mathrm{mCi} / \mathrm{mmol}, \mathrm{NEN})$ for $24 \mathrm{~h}$ in fresh medium. For the retinoic acid-treated chondrocytes, labelling was performed after 5, 12,22 , or 29 days of culture with $20 \mu \mathrm{Ci} / \mathrm{ml}$ of 35S-methionine $(1,000 \mathrm{Ci} / \mathrm{mmol}$, SJ 204 Amersham Pharmacia Biotech) for $14 \mathrm{~h}$ in fresh RPMI lacking methionine and in the absence of fetal calf serum, as previously reported [Freyria et al., 1995a]. After labelling, the media and cell layers were collected and treated separately, as previously described [Freyria et al., 1995a; Ronzière et al., 1997].

The amounts and types of collagens were monitored in both the medium and the cell layer fractions after salt precipitation and pepsin digestion [Freyria et al., 1995a]. Pepsindigested samples were fractionated under reducing and non-reducing conditions on a 7\% sodium dodecylsulfate-polyacrylamide gel (SDS) [Laemmli, 1970]. Aliquots containing a known number of dpm were loaded onto the gels. The bands corresponding to the various types of collagens were visualized by fluorography, and the relative proportions of collagen types I and II were quantified by scanning densitometry with a Personal Densitometer (Molecular Dynamics). As the samples did not represent the same percentage of the corresponding matrix and culture medium and as they were not extracted from the same number of cells, these variations were integrated in the quantitative analysis.

The presence of type $X$ collagen was detected by immunoblot analysis with a mouse anti-deer antibody (a generous gift from G. Gibson [Gibson et al., 1996]). Pepsin-digested samples containing aliquots equivalent to $150 \mu \mathrm{l}$ of the original cell layer extract were applied to each lane, reduced with dithiothreitol and electroblotted onto polyvinylidene difluoride membranes after electrophoresis on $10 \%$ polyacrylamide gels. After the membrane had been blocked with a $1 \%$ bovine serum al bumin solution, the blotted proteins were immunostained with the anti body at a 1:200 di lution, a biotinylated second antibody, biotin-avidin-horseradish peroxidase complex and 4-chloro-1-naphtol as a col or substrate.

The cellular DNA content was determined using bis-benzimidazole (Hoechst 33258) after extraction of the DNA according to Lipman [1989]. DNA calf thymus was used as standard. Cell number was calculated by using a conversion factor of 8 pg DNA per chondrocyte (personal data). Alkaline phosphatase activity was determined with para-nitrophenylphosphateas the substrate [F reyria et al., 1991]. Aliquots (50 $\mu \mathrm{l})$ of the cell layer lysate $(0.1 \%$ Triton $\times 100$ in $0.1 \mathrm{M}$ Tris- $\mathrm{HCl} \mathrm{pH} 8.1 ; 600 \mu \mathrm{l}$ for a $25-\mathrm{cm}^{2}$ flask) were incubated after sonication with $250 \mu$ of substrate. Hydrolysis of the substrate was followed for 5-10 mn at $405 \mathrm{~nm}$ and $37^{\circ} \mathrm{C}$. Proteins in cell lysates were measured with the Pierce microbicinchoninic acid assay kit and bovine serum albumin as the standard. Student's t-test was performed and significant differences were taken as $\mathrm{P}<0.02$.

The secreted proteins were analyzed by twodimensional electrophoresis with Immobiline dry strips pH 3-10.5, pre-cast ExcelGel XL SDS, $12-14 \%$ acrylamide and ExcelGel SDS buffer strips (Amersham Pharmacia Biotech), as previously reported [Freyria et al., 1995a,b]. The culture media were labelled as for the collagen analyses with $50 \mu \mathrm{Ci} / \mathrm{ml}$ of ${ }^{35} \mathrm{~S}$-methionine (1,000 Ci/mmol, SJ 204 Amersham). After 
dialysis and freeze-drying, they were solubilized in Iysis solution (9.8 M urea, 2\% Nonidet P-40, 2\% carrier ampholytes [1.7\% pH 5-7 (Serva) and 0.3\% pH 3-10 (Bio Rad SA)] and $100 \mu \mathrm{M}$ dithiothreitol. The same number of $\mathrm{dpm}$ were loaded for each sample at the cathodic side of the strip and focused at $15^{\circ} \mathrm{C}$ for $22 \mathrm{kVh}$. TheBio Rad two-dimensional polyacrylamide gel electrophoresis (PAGE) marker kit was used for determining molecular mass and pl. After SDS-PAGE, the gels were stained with Coomassie Blue, dried, and autoradiographed on reflection autoradiography film.

\section{RESU LTS \\ Cell Proliferation}

When fetal bovine epiphyseal chondrocytes were grown for 30 days in high-density culture, the DNA content increased slightly throughout the culture in the absence of ascorbic acid, with $24 \pm 2.3 \times 10^{6}$ cells per flask at day 6 and $40 \pm$ $4.6 \times 10^{6}$ cells at day 30 . The presence of ascorbic acid induced a three-fold increase in the DNA content at day $30\left(70.2 \pm 1 \times 10^{6}\right.$ cells) as compared with the level in untreated cultures. The DNA content did not vary over time in the presence of $10 \mu \mathrm{M}$ retinoic acid $(21 \pm 3 \times$ $10^{6}$ cells at day 30 ), whereas a small increase was measured at day $30\left(39 \pm 1 \times 10^{6}\right.$ cells $)$ in cultures treated with ascorbic acid + retinoic acid as compared with the three-fold increase with ascorbic acid al one. The protein content of the cultures followed the changes in cell number.

When the cultures were treated with $\mathrm{DHCB}$ alone or with DHCB + ascorbic acid, a rapid decrease in the DNA content was measured, as cells detached themsel ves from the cultureflask. At day 13 , a mean $30 \%$ decrease was seen with each dose, which reached $50 \%$ at day 23 .

\section{Cell Morphology}

Within 4 weeks in culture under the various conditions, the cells changed in shape and size and in the abundance of extracellular matrix. In the absence of ascorbic acid, the cells had a characteristic round or polygonal morphology with a surrounding matrix after 23 days (Fig. 1a), but after 30 days they appeared to have lost their round shape (Fig. le). In the presence of ascorbic acid, the cells showed extensiveaccumulation of extracellular matrix (Fig. 1c,g). In the presence of $10 \mu \mathrm{M}$ retinoic acid, the cells
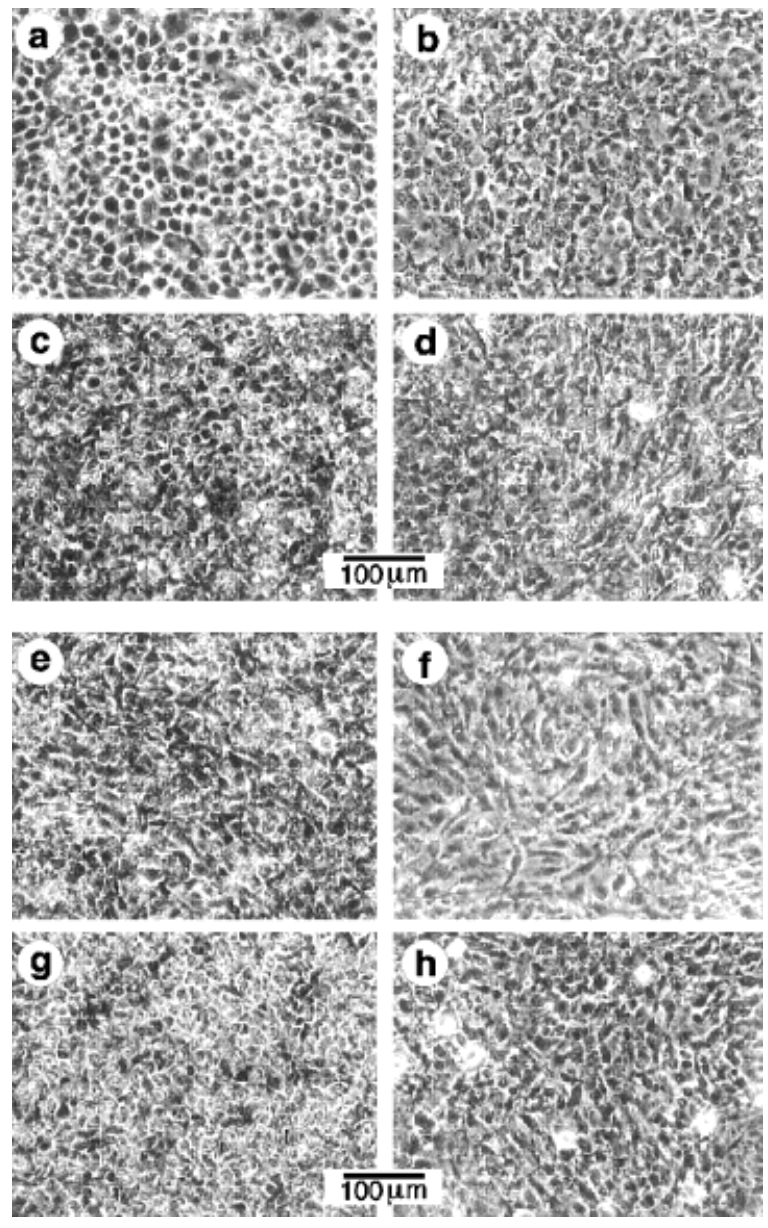

Fig. 1. Phase-contrast photomicrographs of fetal bovine epiphyseal chondrocytes treated with and without retinoic acid. Cultures were observed after 23 days (a- $\mathbf{d})$ and 30 days (e- $\mathbf{h})$ of culture: control $(\mathrm{a}, \mathrm{e})$, ascorbic acid-treated $(\mathrm{c}, \mathrm{g}), 10 \mu \mathrm{M}$ retinoic acid-treated $(b, f)$ and ascorbic acid $+10 \mu \mathrm{M}$ retinoic acidtreated chondrocytes $(\mathrm{d}, \mathrm{h}) ; \times 110$.

lost these characteristic traits and became longer and even smaller than in the control culture (Fig. 1b,f) as more and more were entrapped in the extracellular matrix. The ascorbic acid + retinoic acid-treated cells were shorter and were surrounded by an abundant matrix (Fig. 1d,h). The average cell size did not increase with time in culture, regardless of whether ascorbic acid was present.

The addition of DHCB was followed by a change in cell shape: after $24 \mathrm{~h}$ of treatment with either dose of DHCB, the polygonal cells became rounded and kept this morphology with time of culture (Fig. 2). In contrast to the other culture conditions, in presence of DHCB was observed in only slight deposition of extracelluIar matrix (Fig. 2e). 

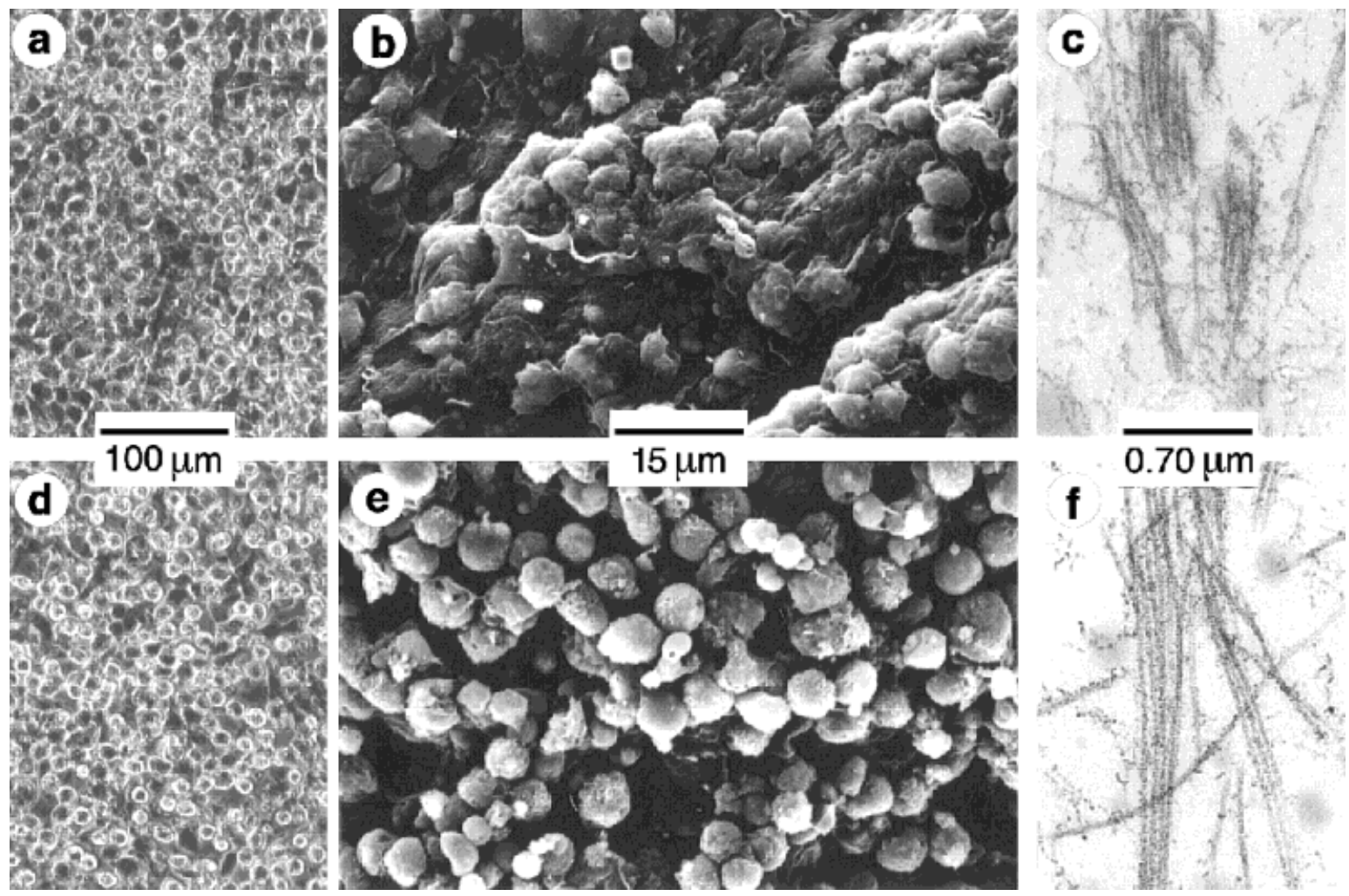

Fig. 2. Phase-contrast and scanning and transmission electron micrographs of fetal bovine epiphyseal chondrocytes treated with and without $10 \mu \mathrm{M}$ dihydrocytochalasin $\mathrm{B}(\mathrm{DHCB})$ after 13 days of culture. No fresh ascorbic acid was added during this period. Chondrocytes in control culture are shown in a, b, c and in the D HCB-treated culture in $\mathbf{d}, \mathbf{e}$, f. $N$ ote the change in morphology and abundance of the pericellular matrix when comparing the controls $a$ and $b$ with D HCB-treated d and e. $\times 142(a, d)$ and $\times 10,000(b, e)$. Chondrocytes are surrounded by fine and striated fibrils $(c, f)$; $\times 21,500$.

\section{Deposition and Composition of the Extracellular Matrix}

As seen by transmission electronic microscopy, cells in the control cultures grew close together throughout the period of culture and were embedded in a loose matrix composed mainly of collagen fibrils of about 13-18 nm in width (Fig. 3a,e), which were either isolated, irregularly spaced, or organized in bundles. In the presence of ascorbic acid, the cells were widely spread at day 23 (Fig. 3c), and at this time many thin filaments were observed that interconnected the fibrils (Fig. $3 g$ ) and resembled a proteoglycan structure. During the 3 weeks of treatment with $10 \mu \mathrm{M}$ retinoic acid, the cells appeared to grow tightly together, with many contacts (Fig. 3b). The extracellular matrix, deposited as a thin network at the boundaries of the cells, was composed mainly of collagen fibrils with a mean thickness of $15 \mathrm{~nm}$ (Fig. 3f). In the culture with the two vitamins (Fig. 3d), the organization and composition of the pericellular matrix (Fig. 3h) resembled that with retinoic acid alone. Chondrocytes grown with $10 \mu \mathrm{M}$ DHCB were rounded and isolated (Fig. 2d), and there was a less abundant pericellular matrix containing fewer collagen fibrils (F ig. 2e); when they were present (Fig. 2f), they were of the same width as in the control culture (Fig. 2c).

\section{Rates of Protein Synthesis and Collagen Typing}

Changes in the total amount of protein, collagen synthesis, and typing in the presence of retinoic acid are presented on Figure 4 . In control cultures with and without ascorbic acid, most total and pepsin-resistant protein synthesis occurred in the cell layer, with a net maximum at day 6 . Addition of $0.5 \mu \mathrm{M}$ retinoic acid suppressed this maximum, with an $80 \%$ decrease in typell collagen (Fig. 4c) and complete inhibition of the synthesis of type I collagen seen with ascorbic acid (Fig. 4d). On day 13, 10 $\mu \mathrm{M}$ retinoic acid were necessary to obtain simi- 
Bovine Epiphyseal Chondrocyte Phenotype Modulation
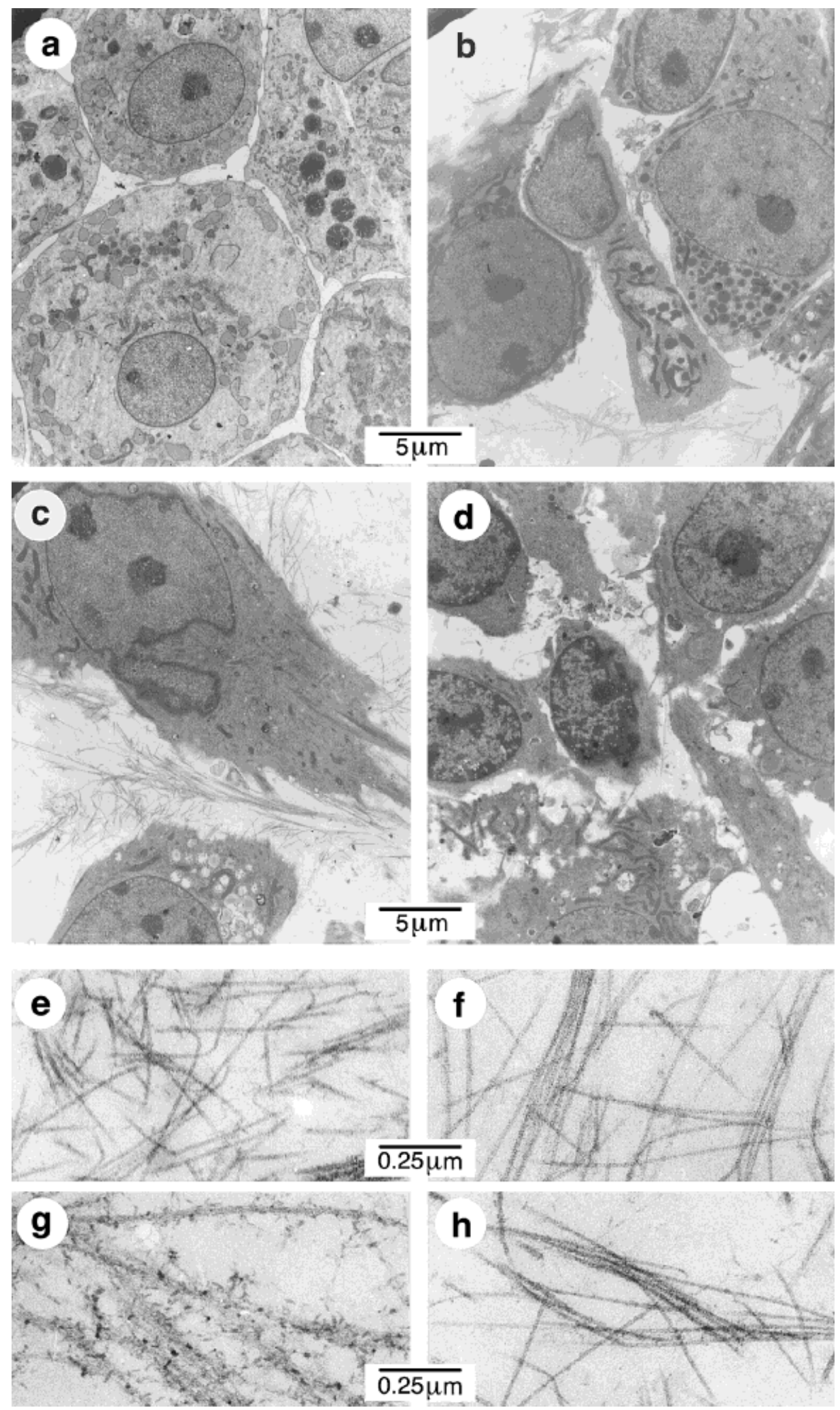

Fig. 3. Transmission electron micrographs of fetal bovine epiphyseal chondrocytes treated with $10 \mu \mathrm{M}$ retinoic acid for 23 days. Cells are shown in $\mathbf{a}-\mathbf{d}$ and the extracellular matrix in $\mathbf{e - h}$; control cultures are shown in a and e, retinoic acid-treated cultures in b and f, ascorbic acid-treated culture in c and $\mathrm{g}$ and ascorbic acid + retinoic acid-treated chondrocytes in $d$ and $h . \times 2500$. Chondrocytes in the various culture conditions are surrounded by fine and striated fibrils $(e-h) ; \times 49,200$. 

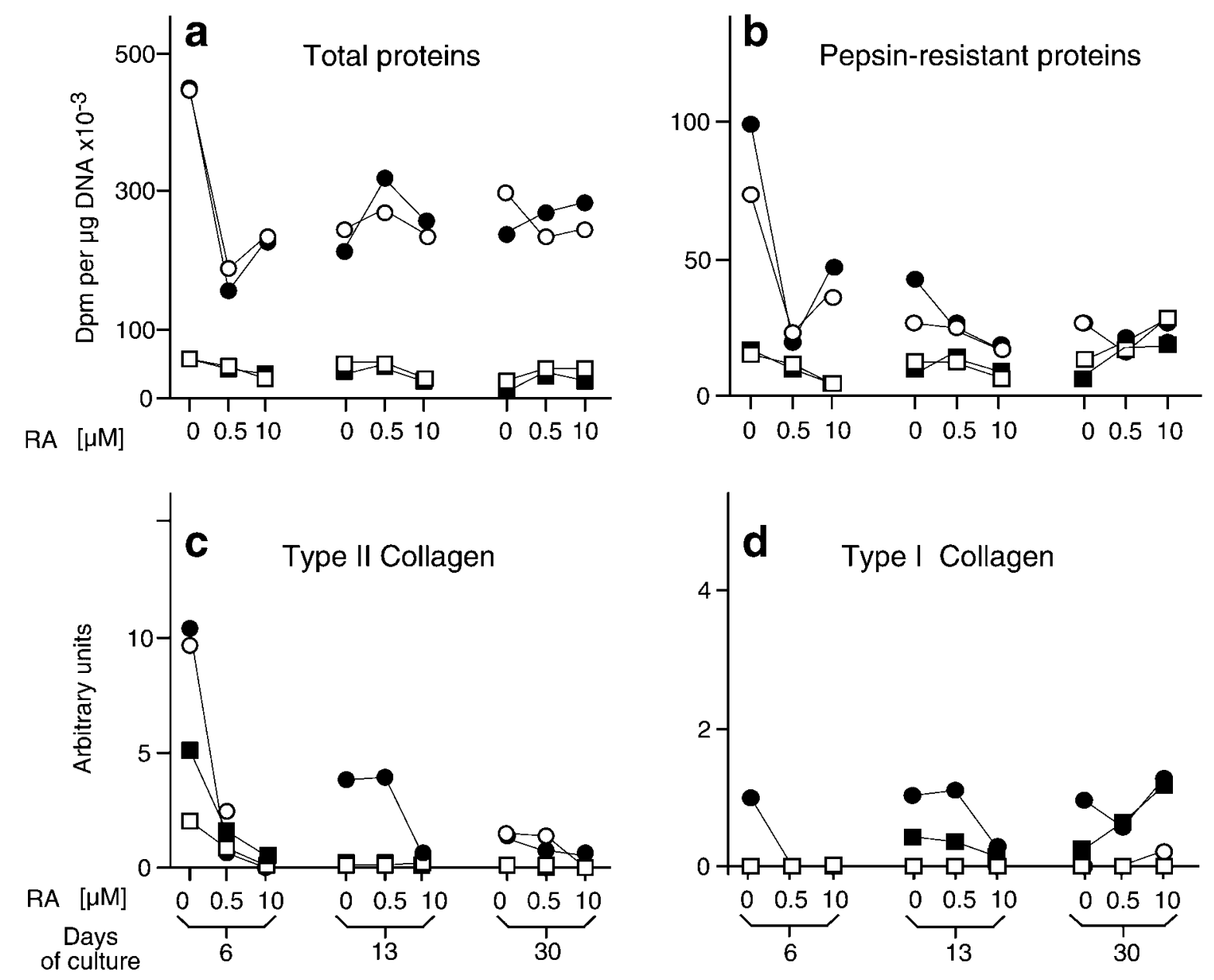

$$
\square \text { medium, Asc (-) } \square \text { medium, Asc (+) } \quad \text { O cell layer, Asc (-) } \quad \text { cell layer, Asc (+) }
$$

Fig. 4. Effects of retinoic acid (RA) alone and with ascorbic acid (Asc) on the uptake of ${ }^{35} \mathrm{~S}$-methionine into newly synthesized total (a) and pepsin-resistant proteins (b) and on the levels of types II (c) and I (d) collagen. Fetal bovine epiphyseal chondrocytes were grown in high-density culture in the presence or absence of 0.5 or $10 \mu \mathrm{M}$ RA and/or Asc. Media and cell layers were collected on days 6,13 , and 30 after labelling for the last $14 \mathrm{~h}$ of each time and submitted to limited pepsin digestion. Samples were precipitated with alcohol, and aliquots equivalent to the same volume of extract were counted in

Iar decreases in types I and II collagen. By day 30, retinoic acid was much less effective: the synthesis level was very low, and type I collagen synthesis was still occurring in cultures with $10 \mu \mathrm{M}$ retinoic acid + ascorbic acid, in both the medium and the cell layer (Fig. 4d).

In the study with DHCB, the rates of total and pepsin-resistant protein synthesis in the medium and the cell layer were comparable in duplicate. The values in $\mathrm{dpm} / \mu \mathrm{g} \mathrm{DNA} \times 10^{-3}$ are the means of counts for three to five different cultures. Cell layer and media samples containing the same number of $\mathrm{dpm}$ were run on a $7 \%$ sodium dodecyl sulfate-polyacrylamide gel to separate the collagens. The relative amounts of types II and I collagen were measured on the fluorographs by densitometry and expressed in arbitrary units as absorbance per microgram of DNA for the total amount in each samples. Values represent the data from one representative single experiment. Comparable results were obtained with chondrocytes isolated from two other fetuses.

control cultures on days 13 and 23, and a twoto three-fold increase in protein was seen with ascorbic acid in the cell layer (Fig. 5). With 3 $\mu \mathrm{M}$ DHCB, a mean $65 \%$ increase in total and pepsin-resistant proteins was seen, independently of the presence of ascorbic acid (Fig. $5 a, b)$. A slight increase in protein synthesis was seen with $10 \mu \mathrm{M}$ DHCB, whereas in the presence of $20 \mu \mathrm{M}$ the level of total protein synthe- 


\section{Bovine Epiphyseal Chondrocyte Phenotype Modulation}
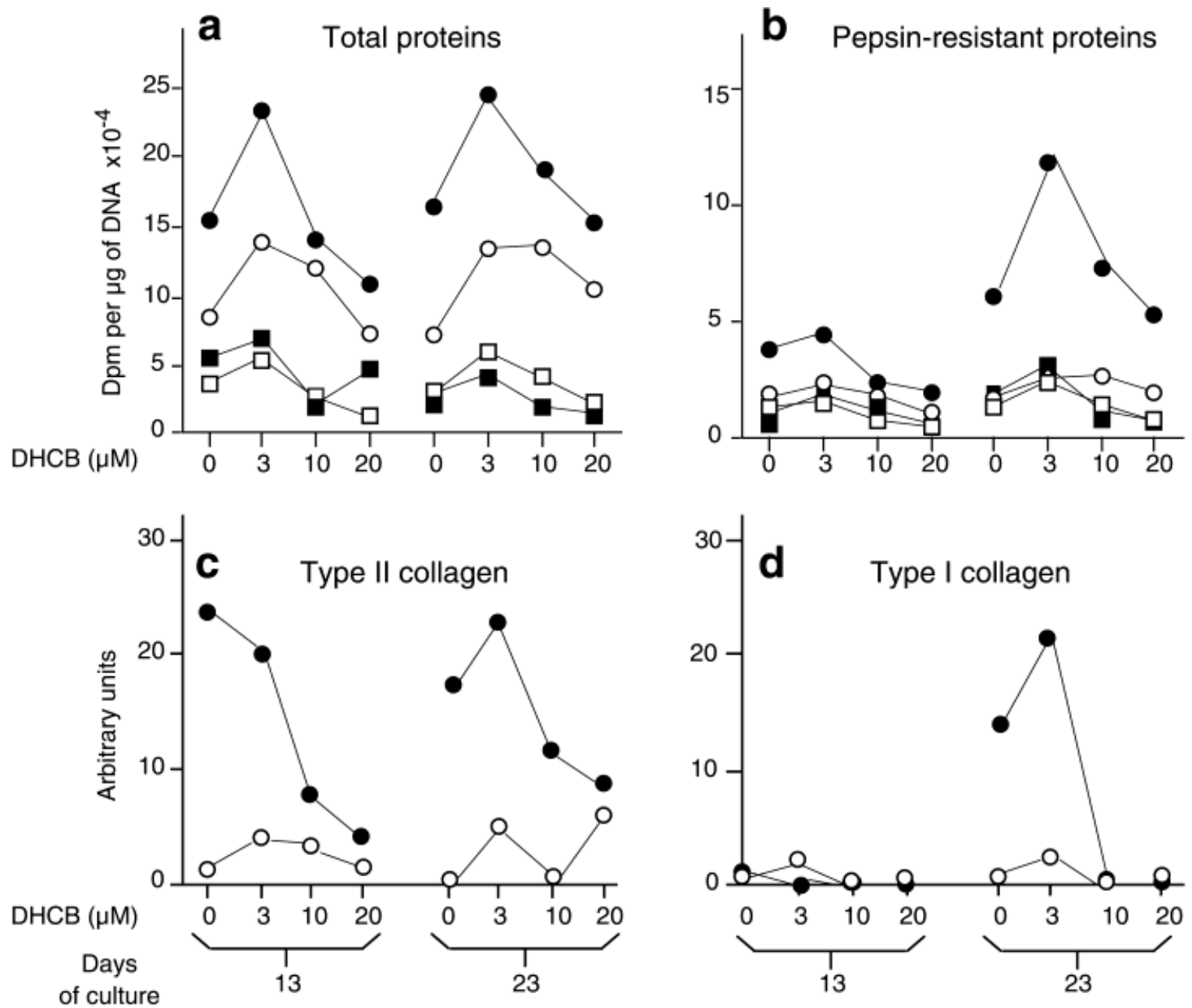

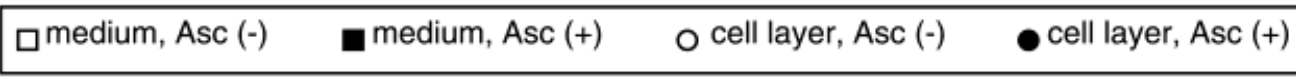

Fig. 5. Effects of dihydrocytochalasin $B(D H C B)$ alone and in combination with ascorbic acid (Asc) on the uptake of ${ }^{14} \mathrm{C}$ proline into newly synthesized total (a) and pepsin-resistant proteins (b) and on the levels of types II (c) and I (d) collagen. Fetal bovine epiphyseal chondrocytes were grown in highdensity culture in the presence or absence of 3,10 , or $20 \mu \mathrm{M}$

sis was close to or below that of the control culture (Fig. 5a). With all three doses, most of the total proteins (70\%) and pepsin-resistant material $(60 \%)$ was found in the cell layer. No change in type I or II collagen synthesis was observed in the cell layer at days 13 and 23 after treatment with $3 \mu \mathrm{M}$ DHCB + ascorbic acid (Fig. 5). With 10 and $20 \mu \mathrm{M}$ DHCB + ascorbic acid, a large decrease in type II collagen synthesis was observed on days 13 and 23, with complete inhibition of type I collagen syn-
DHCB and/or Asc. M edia and cell layers were collected on days 13 and 23 after labelling for the last $24 \mathrm{~h}$ of each time and treated as specified in Figure 4. Values represent the data from one representative single experiment. Comparable results were obtained with chondrocytes isolated from one other fetus.

thesis; the contents of types I and II collagen in the medium were too low to be measured.

\section{Chondrocyte D ifferentiation Markers}

Synthesis of type $X$ collagen was analyzed in both the culture medium and the cell layer after treatment with retinoic acid (Fig. 6). Type $X$ collagen was absent from all culture media throughout culture and from the cell layer in the absence of ascorbic acid with or without retinoic acid. Type $X$ collagen was observed in 


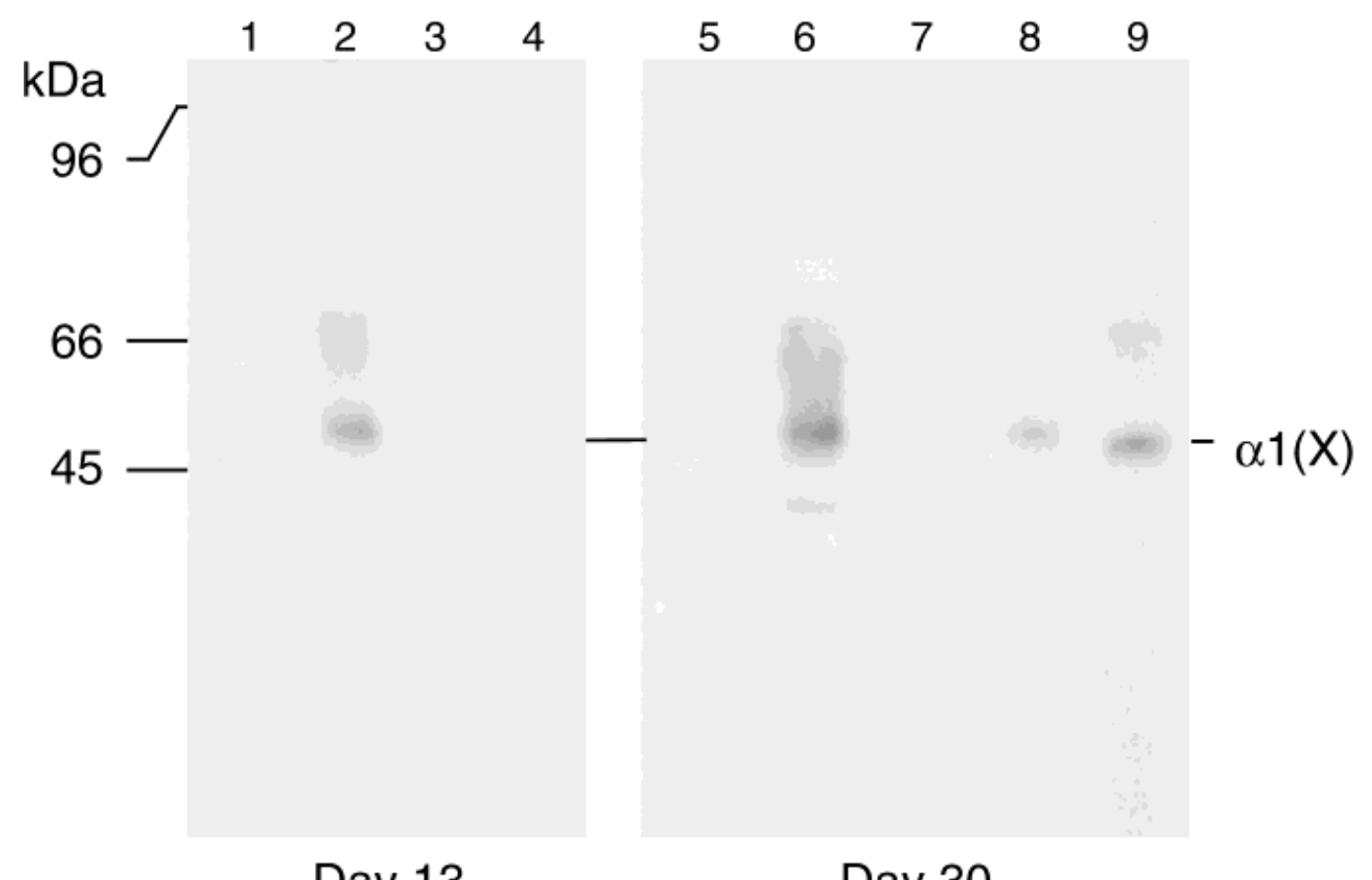

Day 13

Fig. 6. Immunoblot analysis of the effects of ascorbic acid (Asc) and retinoic acid (RA) on type $X$ collagen deposition in the cell layers of chondrocytes. Fetal bovine epiphyseal chondrocytes were grown in high-density culture in the presence or absence of 0.5 or $10 \mu \mathrm{M}$ RA and/or Asc. Cell layers were collected on days 13 and 30 . The pepsin-digested collagens were separated by sodium dodecyl sulfate-polyacrylamide gel electrophoresis, transferred to a polyvinylidene difluoride mem-

brane and probed with antibodies to type $X$ collagen. U ntreated cultures (lanes $\mathbf{1}$ and $\mathbf{5}$ ), and Asc + (lanes 2 and 6) and RAtreated cultures (lanes $\mathbf{3}$ and $\mathbf{7}$ ) are represented on day 13 and 30 , respectively. The combined effects of RA + Asc are represented on day 13 with $10 \mu \mathrm{M}$ RA (lane 4) and on day 30 (lanes 8 and 9) with 0.5 and $10 \mu \mathrm{M}$ RA. Molecular mass markers are shown on the left axis.

TABLE I. Effects of Ascorbic Acid (Asc) and Retinoic Acid (RA) on Alkaline Phosphatase Activity $\left(\mathrm{mU} / 10^{6}\right.$ cells) in Fetal Bovine Epiphyseal Chondrocytes During 30 Days in Culture ${ }^{a}$

\begin{tabular}{|c|c|c|c|c|c|c|}
\hline \multirow{2}{*}{$\begin{array}{l}\text { Days of } \\
\text { treatment }\end{array}$} & \multicolumn{2}{|c|}{$\mathrm{RA} 0 \mu \mathrm{M}$} & \multicolumn{2}{|c|}{ RA $0.5 \mu \mathrm{M}$} & \multicolumn{2}{|c|}{$\mathrm{RA} 10 \mu \mathrm{M}$} \\
\hline & $\operatorname{Asc}(-)$ & $\operatorname{Asc}(+)$ & Asc (-) & $\operatorname{Asc}(+)$ & $\operatorname{Asc}(-)$ & $\operatorname{Asc}(+)$ \\
\hline 13 & $135 \pm 24$ & $167 \pm 33$ & $187 \pm 47$ & $531 \pm 357$ & $378 \pm 113$ & $1308 \pm 232$ \\
\hline 23 & $261 \pm 30$ & $200 \pm 81$ & $111 \pm 13$ & $519 \pm 112$ & $354 \pm 170$ & $3148 \pm 292^{*}$ \\
\hline 30 & $126 \pm 23$ & $55 \pm 17$ & $155 \pm 8$ & $214 \pm 27$ & $656 \pm 182$ & $3565 \pm 89 *$ \\
\hline
\end{tabular}

aChondrocytes were grown in high-density culture in the presence or absence of 0.5 and $10 \mu \mathrm{M}$ RA and/or Asc. Cell layers were collected on days 13, 23, and 30 and alkaline phosphatase activity was measured. Values expressed in milliunit per million of cells ( $\mathrm{mU} / 10^{6}$ cells) represent the average levels \pm SD for three to five independent experiments.

$* \mathrm{P}<0.02$ when untreated cultures were compared with treated cultures.

the cell layer of ascorbic acid-treated cultures at days 13 and 30 of culture and in ascorbic acid + retinoic acid-treated cultures at day 30 (Fig. 6).

Tablel shows thealkaline phosphatase activity in the cell layer during culture. A low mean level of $135.5 \pm 21 \mathrm{mU}$ per $10^{6}$ cells was measured on days 13,23 , and 30 in the control culture, and addition of ascorbic acid did not change this level at any time. In the presence of
$0.5 \mu \mathrm{M}$ retinoic acid, a two- to three-fold increase was observed only in the presence of ascorbic acid. With $10 \mu \mathrm{M}$ retinoic acid and in the absence of ascorbic acid, the increase was only three-fold on day 30 . The presence of both ascorbic acid and $10 \mu \mathrm{M}$ retinoic acid strongly stimulated alkaline phosphatase activity in a time-dependent manner, increasing it statistically by as much as 12 -fold by day $23(P<0.02)$ and 23-26-fold by day 30 ( $P<0.02$ ). No change 


\section{Bovine Epiphyseal Chondrocyte Phenotype Modulation}

in activity could be detected when the cells were grown in the presence of DHCB.

\section{Analysis of Secreted Protein by Two-D imensional Polyacrylamide G el Electrophoresis}

In order to examine the extent of the changes in protein synthesis induced by the various culture conditions, the media were subjected to two-dimensional electrophoresis. We selected three spots on the autoradiographs for comparison of the proteins expressed on the gels. The synthesis of proteins with a molecular mass of less than $29 \mathrm{kDa}$ was down-regulated between days 6 and 13 in the absence of ascorbic acid (Fig. 7a vs. b), whereas acidic proteins with a mass of 45-95 kDa were expressed. The presence of ascorbic acid maintained a high level of expression of the low-molecular-mass proteins after 12 days ( $\mathrm{Fig} .7 \mathrm{~T}, \mathrm{f})$. The subsets of proteins 1,2 , and 3 were also up-regulated in comparison with the untreated culture. Cells grown in the presence of $10 \mu \mathrm{M}$ DHCB (Fig. 7c) ex- pressed nearly the same pattern of secreted proteins as untreated cells in the absence of ascorbic acid (Fig. 7b), but DHCB inhibited the large increase in protein synthesis due to ascorbic acid alone (Fig. $7 \mathrm{~g}$ ). When $10 \mu \mathrm{M}$ retinoic acid were added to the culture, alone (Fig. 7d) or in combination with ascorbic acid (Fig. 7h), the cells had a different pattern of secreted protein from untreated cells (Fig. 7b,f): the lowmolecular-mass proteins were mainly downregulated as early as day 3 of treatment (not shown). Subsets 2 and 3 were no longer detected.

\section{DISCUSSION}

This study provides additional information [Ruggiero et al., 1993; Freyria et al., 1995a,b; Ronzière et al., 1997] about modulation of the phenotype of fetal bovine epiphyseal chondrocytes cultured for up to 30 days in high density in RPMI/NCTC medium containing 10\% fetal calf serum, with or without fresh ascorbic acid

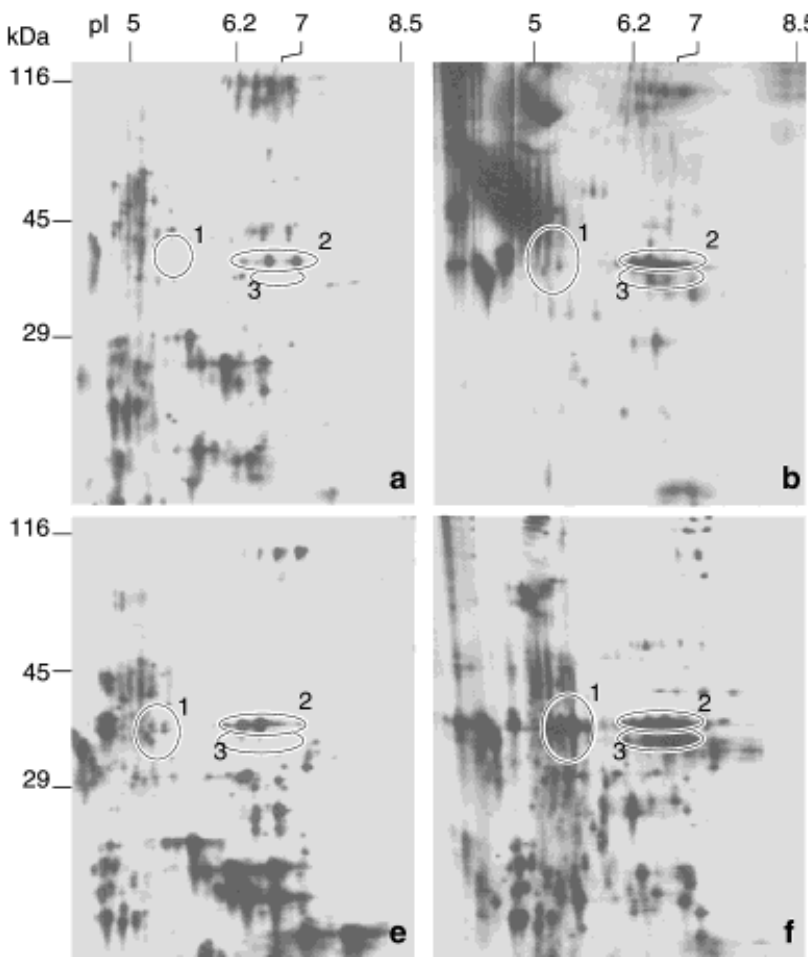

Fig. 7. Two-dimensional polyacrylamide gel electrophoresis autoradiographs of secreted proteins of chondrocytes collected on days 6 and 13 and labelled with ${ }^{35}$ S-methionine for the last $14 \mathrm{~h}$ of culture. Samples containing the same number of counts per minute were separated in the first dimension on Immobiline dry strips pH 3-10.5 and in the second dimension on $12-14 \%$ acrylamide SD S ExcelG el XL. Control chondrocytes grown for 6 (a) or 12 days (b). Ascorbic acid-treated chondrocytes grown for

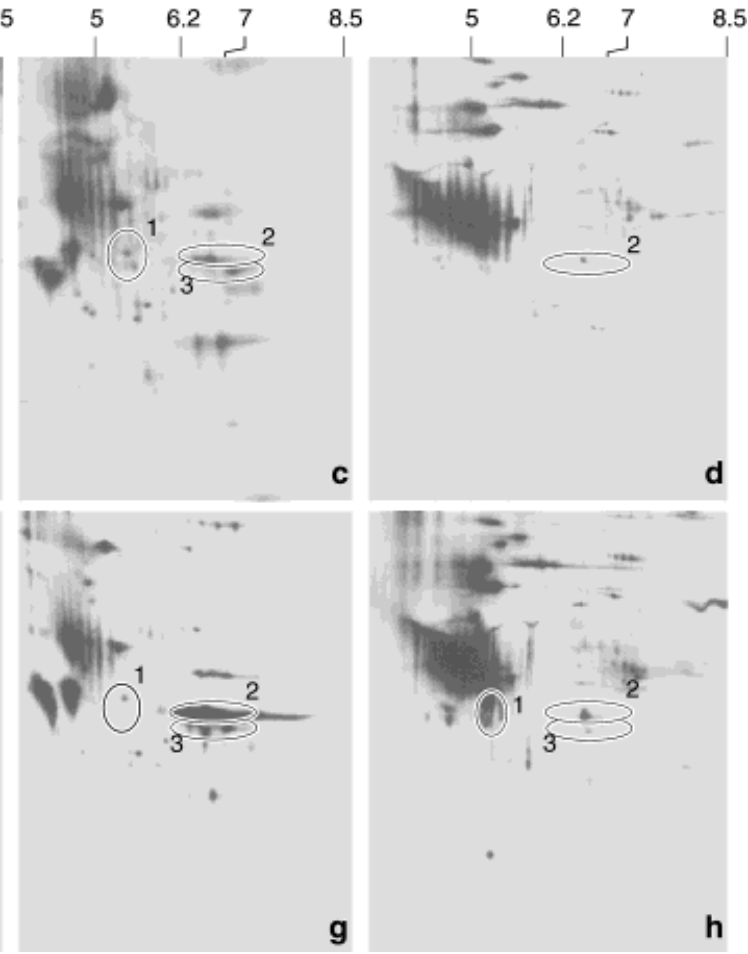

6 (e) or 13 days (f). Chondrocytes treated with $10 \mu \mathrm{M}$ dihydrocytochalasin B for the last 10 days in culture without (c) and with ascorbic acid $(\mathbf{g})$; chondrocytes treated with $10 \mu \mathrm{M}$ retinoic acid for the last 10 days in culture without (d) and with ascorbic acid (h). The apparent molecular masses of known proteins are indicated on the left side. Gels present the data from one representative single experiment. Comparable results were obtained with chondrocytes isolated from one other fetus. 
and in the presence of various concentrations of retinoic acid or DHCB. In the absence of ascorbic acid, chondrocytes have a low proliferation rate $(\times 1.5$ after 1 month), with a rapid decrease in total and pepsin-resistant protein synthesis after six days. The rate of type II collagen synthesis was very low at 13 and 30 days, and no type I collagen was synthesized. No deposition of type $X$ collagen could be detected in the cell layer, and the alkaline phosphatase activity in the medium and cell layer remained very low. Thus, under these conditions, epiphyseal chondrocytes have a stable phenotype with low metabolic activity, as observed in vivo.

Addition of fresh ascorbic acid $(25 \mu \mathrm{g} / \mathrm{ml})$ induced extensive changes in chondrocyte growth and metabolism and in the formation of the extracellular matrix, leading to maturation of the cells: cell proliferation was induced $(\times 3$ after 30 days), and type II collagen was still being synthesized after 13 days; type I collagen synthesis was seen after 6 days (in the cell layer), and type $X$ collagen was present after 13 days. After 30 days, both types I and $X$ collagen were present in the cell layer, whereas the rate of synthesis of type II collagen and the alkaline phosphatase activity were very low. The presence of type $X$ collagen was not associated with cell hypertrophy, in accordance with results obtained in vivo in the chick growth plate [Oshima et al., 1989] and in vitro with immature sternal chondrocytes [Pacifici et al., $1991 a, b]$ or with cells isolated from the mandibular ectomesenchyme [E kayanakeand Hall, 1994]. Similar data on proliferation, the expression of types I and II collagen genes and the synthesis of these types were observed [Daniel et al., 1984; Hering et al., 1994] with adol escent bovine articular chondrocytes plated at high density and grown in the presence of ascorbic acid. Several studies with chicken chondrocytes (epiphyseal, growth plate, or sternal cells) have shown that ascorbic acid stimulates type $X$ collagen synthesis and matrix cal cification [Tacchetti et al., 1987; Leboy et al., 1989; Wu et al., 1989; Gerstenfeld and Landis, 1991; Shapiro et al., 1991; Sullivan et al., 1994; Leboy et al., 1997; Farquharson et al., 1998]. Ballock et al. [1993] showed that chondrocytes isolated from the reserve zone of the epiphyses of neonatal rats and cultured as a three-dimensional cell pellet with fresh ascorbic acid acquired a hypertrophic phenotype by day 28 with expression of type $X$ collagen and inhibition of type II colla- gen. This terminal differentiation was inhibited by TGF beta-1. In constrast, Kirsch et al. [1992] have shown that in the absence of ascorbic acid fetal human chondrocytes in long-term culture in suspension over agarose differentiate into so-called 'post-hypertrophic' chondrocytes, which synthesize types I and X collagen. Under these culture conditions, addition of ascorbic acid during the initial phase inhibited the passage to hypertrophic cells, perhaps due to production of radicals to which human chondrocytes may be more sensitive than bovine, rat, or chicken chondrocytes [Tschan et al., 1990].

Retinoic acid is one of the more biologically active derivatives of retinol (vitamin A). It functions as an important regulatory signalling molecule for cell growth and differentiation both during embryogenesis and in the adult animal [Gudas, 1994]. It regulates the expression of genes directly through interactions with DNAbinding retinoic acid receptors, the gamma subtype of which is found predominantly in cartilage [Kastner et al., 1990]. We have shown here that addition of high doses of retinoic acid $(0.5$ and $10 \mu \mathrm{M}$ ) to a culture medium in the absence of fresh ascorbic acid does not modify the metabolic activity or the phenotype of fetal bovine epiphyseal chondrocytes in high-density culture. Addition of retinoic acid in combination with ascorbic acid decreased the cell proliferation induced by ascorbic acid and suppressed the high level of total protein and collagen II and I synthesis observed at day 6 . The synthesis of types I and X collagen was delayed but these two collagens were present at day 30 . The presence of type $X$ collagen, a marker of maturation, was again not associated with hypertrophy of the cells, as al ready shown with ascorbic acid without retinoic acid. Interestingly, with $10 \mu \mathrm{M}$ retinoic acid + ascorbic acid, we observed a striking increase in alkaline phosphatase activity in comparison with that seen with each vitamin alone (15-25-fold increase at days 23 and 30). At day 30, no mineralization of the matrix was found, probably because beta-glycerophosphate, a well-known activator of calcification, was not added to the culture medium [Chung et al., 1992; Coe et al., 1992].

Previous studies have also shown that retinoic acid inhibits the expression of the genes coding for cartilage matrix proteins such as typell collagen [Benya and Padilla, 1986; Horton et al., 1987]. It has also been shown that retinoic acid induces maturation and matrix 


\section{Bovine Epiphyseal Chondrocyte Phenotype Modulation}

mineralization specifically in pre-hypertrophic cells, isolated from the cephalic portion of the chicken sternum or from growth plate cartilage [Oettinger and Pacifici, 1990; Pacifici et al., 1991a,b; I wamoto et al., 1993a, 1994; Wu et al., 1997]; however, alkaline phosphatase and mineralization were not induced in immature chondrocytes isolated from the caudal region of the chick embryo sternum in the presence of 35 or $100 \mathrm{nM}$ retinoic acid, with or without ascorbic acid [Pacifici et al., 1991b; I wamoto et al., 1993a, 1994]. Thus, our results demonstrate for the first time that combined treatment with ascorbic acid and high doses of retinoic acid is necessary to induce both maturation of fetal epiphyseal chondrocytes and stimulation of alkaline phosphatase activity.

Regulation of the gene expression of alkaline phosphatase by retinoic acid $(1 \mu \mathrm{M})$ has been demonstrated at both the transcriptional and post-transcriptional level [Zhou et al., 1994]. Other mechanisms of action of retinoids in chondrocytes include modulation of their integrinmediated attachment to extracellar matrix proteins [Loeser, 1994; Sanchez et al., 1996] and up-regulation of metalloprotease genes [Ballock et al., 1994; Nie et al., 1998]. The importance of retinoic acid in regulating protein synthesis by fetal epiphyseal chondrocytes is well demonstrated by the numerous modifications induced in the pattern of secreted proteins, at both the quantitative and qualitative levels. Two-dimensional electrophoresis is a powerful technique for analysing complex mixtures of proteins, and specific differences in map composition were revealed when extracellular proteins derived from fibroblastic and osteoblastic cells were compared [Hankey et al., 1992]. This technique was used by Mathieu et al. [1994] to identify novel proteins as markers of osteoblast differentiation. In our laboratory, changes in the chondrocyte phenotype were recorded in two-dimensional patterns after induction by retinoic acid as a decrease in type II collagen synthesis and expression of the small proteoglycan, decorin [F reyria et al., 1995b]. In the present study, major changes occurred on day 13, when type I collagen was strongly expressed in culture with ascorbic acid and suppressed by retinoic acid. This inducer further counteracted the effect of ascorbic acid on the expression of various proteins in the extracellular compartments. In the culture grown without ascorbic acid, in which retinoic acid delayed maturation of the chondrocytes, little variation was seen in the level of secreted proteins, suggesting that themechanisms for this effect involve few extracellular proteins. Another important inhibitor of the maturation of fetal bovine epiphyseal chondrocytes induced by ascorbic acid in our culture conditions is DHCB. After addition of 10 or $20 \mu \mathrm{M}$ DHCB to the culture medium, with or without fresh ascorbic acid, chondrocytes maintained their round morphol ogy and showed a dramatic decrease in total and collagen protein synthesis, leading to a low deposition of extracellular matrix and partial detachment of the cells. Synthesis of types I and X collagen and alkaline phosphatase activity were completely inhibited, demonstrating that a cartilage phenotype with a low level of type II collagen synthesis and a pattern of secreted proteins is maintained after 13 days. This is very similar to the pattern obtained without ascorbic acid. It was reported previously that $\mathrm{DHCB}$, a microfilament-modifying agent, enhances the expression of chondroblastic markers by rat mesenchymal cells cultured with cartilage-inducing factor [Rosen et al., 1986] or can cause restoration of type II collagen synthesis by dedifferentiated chondrocytes [Benya et al., 1988; Brown and Benya, 1988; Benya and Padilla, 1993] indicating a potential role of the cytoskeleton in the maintenance of the phenotype. The disruption of the cytoskel eton microfilament by DHCB has been also reported to inhibit beta-1 integrin increased-expression by TGF-beta-1 in articular chondrocytes [Loeser et al., 1995]. CytochaIasin B was reported to inhibit the transport of dehydroascorbic acid in human neutrophils through the inhibition of the hexose transport system [Vera et al., 1993]. Similar mechanisms may be involved, in the bovineepiphyseal chondrocytes, regarding the inhibition of ascorbic acid effects by DHCB.

In conclusion, the phenotype of fetal bovine epiphyseal chondrocytes appears to be modified readily in high-density culture by the addition of inducers such ascorbic acid, retinoic acid and DHCB. Depending on the culture conditions, cells showed a maintained, a partially dedifferentiated or a terminally differentiated phenotype with expression of type $X$ collagen, with or without high al kaline phosphatase activity. Our two-dimensional PAGE analyses have also shown that the changes in the chondrocyte phenotype are accompanied by extensive changes in the pattern of excreted proteins. 
Complete identification of these proteins would be useful for defining the mechanisms involved more precisely.

\section{ACKN O WLED G MENTS}

We thank Dr G. Gibson (Breeche Research Laboratory, Henry Ford Hospital, Detroit, MI) for his generous gift of anti-type $X$ collagen and Dr J . Guidollet (INSERM U 189, Hopital LyonSud, Lyon, France) for assistance with measuring alkaline phosphatase activity. Wealso thank R. Willems and R. Pillot for expert technical assistance and C. Van Herrewege and A. Bosch for assistance in preparing the manuscript.

\section{REFEREN CES}

Adams LA, Palante KM, Niu Z, Leboy PS, Golden EB, Pacifici M. 1991. Rapid induction of type X collagen gene expression in cultured chick vertebral chondrocytes. Exp Cell Res 193:190-197.

Adolphe M, Benya PD. 1992. Different types of cultured chondrocytes. Thein vitro approach to thestudy of biological regulation. In: Adolphe M, editor. Biological regulation of the chondrocytes. Boca Raton, FL: CRC Press. $p$ 105-139.

Aydelotte MB, Schleyerbach R, Zeck BJ, Kuettner KE. 1986. Articular chondrocytes cultured in agarose gel for study of chondrocytic chondrolysis. In: Kuettner KE, Schleyerbach R, Hascall VD, editors. Articular cartilage biochemistry. New York: Raven Press. p 235-256.

Ballock RT, Heydemann A, Wakefield LM, Flanders KC, Roberts AB, Sporn MB. 1993. TGF -betal prevents hypertrophy of epiphyseal chondrocytes: regulation of gene expression for cartilage matrix proteins and metalloproteases. Dev Biol 158:414-429.

Ballock RT, Heydemann A, Wakefield LM, Flanders KC, Roberts AB, Sporn MB. 1994. Inhibition of the chondrocyte phenotype by retinoic acid involves upregulation of metalloprotease genes independent of TGF-beta. J Cell Physiol 159:340-346.

Benya PD, Padilla SR. 1986. Modulation of the rabbit chondrocyte phenotype by retinoic acid terminates type II collagen synthesis without inducing type I collagen: the modulated phenotype differs from that produced by subculture. Dev Biol 118:296-305.

Benya PD, Padilla SR. 1993. Dihydrocytochalasin B enhances transforming growth factor-beta-induced reexpression of the differentiated chondrocyte phenotype without stimulation of collagen synthesis. Exp Cell Res 204:268277.

Benya PD, Shaffer J D. 1982. Dedifferentiated chondrocytes reexpress the differentiated collagen phenotype when cultured in agarose gels. Cell 30:215-224.

Benya, PD, Padilla, SR, Nimni ME. 1978. Independent regulation of collagen types of chondrocytes during the loss of differentiated function in culture. Cell 15:13131321.

Benya PD, Brown PD, Padilla SR. 1988. Microfilament modification by dihydrocytochalasin $B$ causes retinoic acid-modulated chondrocytes to reexpress the differenti- ated collagen phenotype without a change in shape. J Cell Biol 106:161-170.

Brighton CT. 1978. Structure and function of the growth plate. Clin Orthop 136:22-32.

Brown PD, Benya PD. 1988. Alterations in chondrocyte cytoskeletal architecture during phenotypic modulation by retinoic acid and dihydrocytochalasin B-induced reexpression.J Cell Biol 106:171-179.

Bruckner P, Horler I, Mendler M, Houze Y, Winterhalter KH, Eich-Bender SG, Spycher M. 1989. Induction and prevention of chondrocyte hypertrophy in culture. J Cell Biol 109:2537-2545.

Cancedda R, Descalzi Cancedda F, Castagnola P. 1995. Chondrocyte differentiation. Int Rev Cytol 159:265-358.

Castagnola P, Moro G, Descalzi Cancedda F, Cancedda, R. 1986. Type $X$ collagen synthesis during in vitro development of chick embryo tibial chondrocytes. J Cell Biol 102:2310-2317.

Chen P, Vukicevic S, Sampath TK, Luyten FP. 1995. Osteogenic protein-1 promotes growth and maturation of chick sternal chondrocytes in serum-free cultures. J Cell Sci 108:105-114.

Chung C-H, Golub EE, Forbes E, Tokuoka T, Shapiro I M. 1992. Mechanism of action of beta-glycerophosphate on bone cell mineralization. Calcif Tissue Int 51:305-311.

Coe MR, Summers TA, Parsons SJ , Boskey AL, Balian G. 1992. Matrix mineralization in hypertrophic chondrocyte cultures. Beta glycerophosphate increases type $X$ collagen messenger mRNA and the specific activity of pp60c-src kinase. Bone Miner 18:91-106.

Daniel J C, Pauli BU, Kuettner KE. 1984. Synthesis of cartilage matrix by mammalian chondrocytes in vitro. III Effects of ascorbate. J Cell Biol 99:1960-1969.

Dietz U, Aigner T, Bertling WM, von der Mark K. 1993. Alterations of collagen mRNA expression during retinoic acid induced chondrocyte modulation: absence of untranslated alpha 1(I) mRNA in hyaline chondrocytes. J Cell Biochem 52:57-68.

Ekayanabe S, Hall BK. 1994. Hypertrophy is not a prerequisite for type $X$ collagen expression or mineralization of chondrocytes derived from cultured chick mandibular ectomesenchyme. Int J Dev Biol 38:683-694.

Farquharson C, Whitehead CC. 1995. Differentiation and mineralization in chick chondrocytes maintained in a high cell density culture: a model for endochondral ossification. In vitro Cell Dev Biol 31:288-294.

Farquharson C, Berry J L, Mawer EB, Seawright E, Whitehead CC. 1998. Ascorbic acid-induced chondrocyte terminal differentiation: the role of the extracellular matrix and 1,25-dihydroxyvitamin D. Eur J Cell Biol 76:110118.

Freyria A-M, Chignier E, Guidollet J, Louisot P. 1991. Peritoneal macrophage response: an in vivo model for the study of synthetic materials. Biomaterials 12:111-118.

Freyria $A-M$, Ronzière $M-C$, Boutillon $M-M$, Herbage $D$. 1995a. Effect of retinoic acid on protein synthesis by fetal bovine chondrocytes in high-density culture: downregulation of the glucose-regulated protein, GRP-78 and typell collagen. Biochem J 305:391-396.

Freyria A-M, Ronziere M-C, Boutillon M-M, Herbage D. 1995b. Two-dimensional electrophoresis of intracellular and secreted protein synthesized by fetal bovinechondrocytes in high-density culture. Electrophoresis 16:12681272. 


\section{Bovine Epiphyseal Chondrocyte Phenotype Modulation}

Gerstenfeld LC, Landis WJ. 1991. Gene expression and extracellular matrix ultrastructure of a mineralizing chondrocyte cell culture system. J Cell Biol 112:501-513.

Gibson GJ , Schor SL, Grant ME. 1982. Effects of matrix macromolecules on chondrocyte gene expression : synthesis of a low molecular weight collagen species by cells cultured within collagen gels. J Cell Biol 93:767-774.

Gibson GJ , Lin D-L, Francki K, Caterson B, Foster B. 1996. Type $X$ collagen is col ocalized with a proteoglycan epitope to form distinct morphological structures in bovine growth cartilage. Bone 19:307-315.

Gudas LJ . 1994. Retinoids and vertebrate development. J Cell Biol 269:15399-15402.

Guo J , J ourdian GW, MacCallum DK. 1989. Culture and growth characteristics of chondrocytes encapsulated in al ginate beads. Connect Tissue Res 19:277-297.

Hankey DP, Nicholas RM, Hughes AE. 1992. Two-dimensional polyacrylamide gel electrophoresis reveals differences between osteoblast and fibroblast extracellular proteins. Electrophoresis 13:329-332.

Harmand MF, Duphil R, Blanquet P. 1982. Proteoglycan synthesis in chondrocyte cultures from osteoarthritic and normal human articular cartilage. Biochim Biophys Acta 717:190-202.

Häuselmann HJ , Aydel otte MB, Schumacher BL, Kuettner KE, Gitelis SH, Thonar EJ -MA. 1992. Synthesis and turnover of proteoglycans by human and bovine adult articular chondrocytes cultured in al ginate beads. Matrix 12:116-129.

Hering TM, Kollar J , Huynh TD, Varelas J B, Sandell LJ . 1994. Modulation of extracellular matrix gene expression in bovine high-density chondrocyte cultures by ascorbic acid and enzymatic resuspension. Arch Biochem Biophys 314:90-98.

Hickock NJ , Haas AR, Tuan RS. 1998. Regulation of chondrocyte differentiation and maturation. Micro Res Tech 43:174-190.

Horton EW, Yamada Y, Hassell J R. 1987. Retinoic acid rapidly reduces cartilage matrix synthesis by altering gene transcription in chondrocytes. Dev Biol 123:508516.

Horwitz AL, Dorfman A. 1970. The growth of cartilage cells in soft agar and liquid suspension. J Cell Biol 45:434438.

Hunzinker EB. 1994. Mechanism of Iongitudinal bone growth and its regulation by growth plate chondrocytes. Micro Res Tech 28:505-519.

I wamoto M, Sato K, Nakashima K, Shimazu A, Kato Y. 1989. Hypertrophy and calcification of rabbit permanent chondrocytes in pelleted cultures: synthesis of alkaline phosphatase and 1,25-dihydroxycholecalciferol receptor. Dev Biol 136:500-507.

I wamoto M, Golden EB, Adams SL, Noji S, Pacifici M. 1993a. Responsiveness to retinoic acid changes during chondrocyte maturation. Exp Cell Res 205:213-224.

I wamoto M; Shapiro IM, Yagami K, Boskey AL, Leboy PS, Adams SL, Pacifici M. 1993b. Retinoic acid induces rapid mineralization and expression of mineralization-related genes in chondrocytes. Exp Cell Res 207:413-420.

I wamoto M, Yagami K, Shapiro IM, Leboy PS, Adams SL, Pacifici M. 1994. Retinoic acid is a major regulator of chondrocyte maturation and matrix mineralization. Micro Res Tech 28:483-491.

Kastner P, Krust A, Mendelsohn C, Garnier J M, Zelent A, Leroy P, Staub A, Chambon P. 1990. Murine isoforms of retinoic acid receptor gamma with specific patterns of expression. Proc Natl Acad Sci USA 87:2700-2704.

Kato Y, I wamoto M, Koike T, Suzuki F, Takano Y. 1988. Terminal differentiation and calcification in rabbit chondrocyte cultures grown in centrifuge tubes: regulation by transforming growth factor beta and serum factors. Proc Natl Acad Sci USA 85:9552-9556.

Kimura T, Yasui N, Ohsawa S, Ono K. 1984. Chondrocytes embedded in collagen gels maintain cartilage phenotype during long-term cultures. Clin Orthop 186:231-239.

Kirsch T, Swoboda B, von der Mark K. 1992. Ascorbate independent differentiation of human chondrocytes in vitro: simultaneous expression of types I and $X$ collagen and matrix mineralisation. Differentiation 52:89-100.

KoyanoY, Hejna M, Flechtenmacher J , Schmid TM, Thonar EJ -MA, Mollenhauer J . 1996. Collagen and proteoglycan production by bovine fetal and adult chondrocytes under low levels of calcium and zinc ions. Connect Tissue Res 34:213-225.

Kuettner KE, Pauli BU, Gall G, Memoli VA, Schenk RK. 1982. Synthesis of cartilage matrix by mammalian chondrocytes in vitro. I. I solation, culture characteristics, and morphology. J Cell Biol 93:743-750.

LabourdetteL, Herbage D, Mallein-Gerin F. 1996. Chondrocytes in culture: a useful tool for studying cartilage structure, development and repair. Cell Eng 1:200-208.

Laemmli UK. 1970. Cleavage of structural proteins during the assembly of the head of bacteriophage T4. Nature 227:680-685.

Leboy PS, Vaias L, Uschmann B, Golub E, Adams SL, Pacifici M. 1989. Ascorbic acid induces alkaline phosphatase, type $X$ collagen and calcium deposition in cultured chick chondrocytes. J Biol Chem 264:17281-17286.

Leboy PS, Sullivan TA, Nooreyazdan M, Venezian RA. 1997. Rapid chondrocyte maturation by serum-free culture with BMP-2 and ascorbic acid. J Cell Biochem 66: 394-403.

Lipman, J .M. 1989. Fluorophotometric quantitation of DNA in articular cartilage utilizing Hoechst 33258. Anal Biochem 176:128-131.

Loeser RF. 1994. Modulation of integrin-mediated attachment of chondrocytes to extracellular matrix proteins by cations, retinoic acid, and transforming growth factor beta. Exp Cell Res 211:17-23.

Loeser RF, Carlson CS, McGee MP. 1995. Expression of betal integrins by cultured articular chondrocytes and in osteoarthritic cartilage. Exp Cell Res 217:248-257.

Mathieu E, Meheus L, Raymackers J , Merregaert J . 1994. Characterization of the osteogenic stromal cell line MN7: identification of secreted MN 7 proteins using two-dimensional gel electrophoresis, western blotting and microsequencing. J Bone Min Res 9:903-913.

Nie D, Ishikawa Y, Yoshimori T, Wuthier RE, Wu LNY. 1998. Retinoic acid treatment el evates matrix metalloproteinase 2 protein and mRNA levels in avian growth plate chondrocyte cultures. J Cell Biochem 69:90-99.

Oettinger HF, Pacifici M. 1990. TypeX collagen geneexpression is transiently up-regulated by retinoic acid treatment in chick chondrocytecultures. Exp Cell Res 191:292298.

Oshima O, Leboy PS, McDonald SA, Tuan RS, Shapiro I M. 1989. Developmental expression of genes in chick growth cartilage detected by in situ hybridization. Calcif Tissue Int 45:182-192. 
Pacifici M, Oettinger HF. 1985. Stable phenotypic expression by chick chondroblasts in long-term suspension culture as determined by proteoglycan analysis. Exp Cell Res 161:381-392.

Pacifici M, Golden EB, Adams SL, Shapiro IM. 1991a. Cell hypertrophy and type $X$ collagen synthesis in cultured articular chondrocytes. Exp Cell Res 192:266-270.

Pacifici M, Golden EB, I wamoto M, Adams SL. 1991b Retinoic acid treatment induces type $X$ collagen gene expression in cultured chick chondrocytes. Exp Cell Res 195: 38-46.

Ronzière M-C, Farjanel J , Freyria A-M, Hartmann DJ , Herbage D. 1997. Analysis of types I, II, III, IX and XI collagens synthesized by fetal bovine chondrocytes in high-density culture. Osteoarth Cartil 5:205-214.

Rosen DM, Stempien SA, Thompson AY, Brennan J E, Ellingsworth LR, Seyedin SM. 1986. Differentiation of rat mesenchymal cells by cartilage-inducing factor. Enhanced phenotypic expression by dihydrocytochalasin B. Exp Cell Res 165:127-138.

Ruggiero F, Petit B, Ronzière M-C, Farjanel J , Hartmann D, Herbage D. 1993. Composition and organization of the collagen network produced by fetal bovine chondrocytes cultured at high density.J Histochem Cytochem 41:867-875.

Sanchez M, Gionti E, Pontarelli G, Arcella A, De Lorenzo F. 1991. Alpha 2(I) collagen gene expression is up-regulated in quail chondrocytes pretreated with retinoic acid. BiochemJ 276:183-187.

Sanchez M, Arcella A, Pontarelli G, Gionti E. 1996. Therole of cell adhesion in retinoic acid-induced modulation of chondrocyte phenotype. BiochemJ 313:201-206.

Sandberg M M. 1991. Matrix in cartilage and bone development: current views on the function and regulation of major organic components. Ann Med 23:207-217.

Shapiro IM, Leboy PS, Tokuoka T, Forbes E, DeBolt K, Adams SL, Pacifici M. 1991. Ascorbic acid regulates multiple metabolic activities of cartilage cells. Am J Clin Nutr 54:1209S-1213S.

Solursh M. 1989. Differentiation of cartilage and bone. Curr Opin Cell Biol 1:989-994.
Stephens M, Kwan APL, Bayliss MT, Archer CW. 1992. Human articular surface chondrocytes initiate alkaline phosphatase and type $X$ synthesis in suspension culture. J Cell Sci 103:1111-1116.

Sullivan TA, Uschmann B, Hough R, Leboy PS. 1994. Ascorbate modulation of chondrocyte gene expression is independent of its role in collagen secretion. J Biol Chem 269:22500-22506.

Tacchetti C, Quarto R, Nitsch L, Hartmann DJ , Cancedda R. 1987. In vitro morphogenesis of chick embryo hypertrophic cartilage. J Cell Biol 105:999-1006.

Takishita Y, Hiraiwa K, Nagayama M. 1990. Effect of retinoic acid on proliferation and differentiation of cultured chondrocytes in terminal differentiation. Biochem J 107: 592-596.

Tschan T, Hoerler I, Houze Y, Winterhalter KH, Richter C, Bruchner P. 1990. Resting chondrocytes in culture survive without growth factors, but are sensitive to toxic oxygen metabolites. J Cell Biol 111:257-260.

Venezian R, Shenker BJ , Datar S, Leboy PS. 1998. Modulation of chondrocyte proliferation by ascorbic acid and BMP-2.J Cell Physiol 174:331-341.

Vera J C, Rivas Cl, Fischbarg J , Golde DW. 1993. Mammalian facilitative hexose transporters mediate the transport of dehydroascorbic acid. Nature 364:79-82.

Wu LNY, I shikawa Y, Nie D, Genge BR, Wuthier RE. 1997. Retinoic acid stimulates matrix calcification and initiates type I collagen synthesis in primary cultures of avian weight-bearing plate chondrocytes. J Cell Biochem 65: 209-230

Yasui N, Benya PB, Nimni ME. 1986. Coordinate regulation of type IX and type II collagen synthesis during growth of chick chondrocytes in retinoic acid or 5-bromo2'-deoxyuridine. J Biol Chem 261:7997-8001.

Zhou H, Manji SS, Findlay DM, Martin TJ , Heath J K, Ng KW. 1994. Novel action of retinoic acid. Stabilization of newly synthesized alkaline phosphatase transcripts. J Biol Chem 269:22433-22439. 